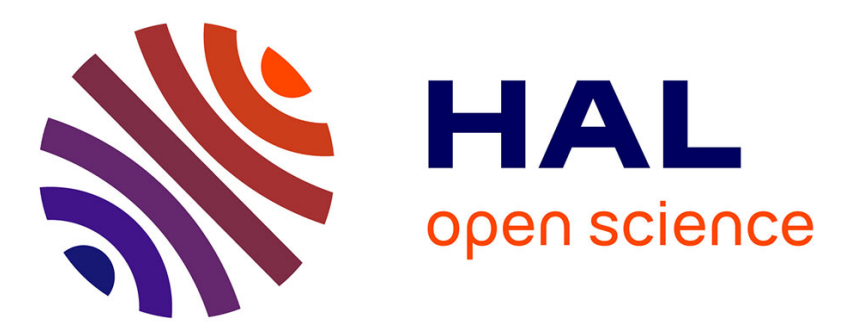

\title{
Reductive dehalogenation of 1,3-dichloropropane by a [Ni(tetramethylcyclam)]Br2-Nafion modified electrode
}

Jean-Marie Fontmorin, Wenyan He, Didier Floner, Florence Fourcade, Abdeltif Amrane, Florence Geneste

\section{- To cite this version:}

Jean-Marie Fontmorin, Wenyan He, Didier Floner, Florence Fourcade, Abdeltif Amrane, et al.. Reductive dehalogenation of 1,3-dichloropropane by a [Ni(tetramethylcyclam)]Br2-Nafion modified electrode. Electrochimica Acta, 2014, 137, pp.511-517. 10.1016/j.electacta.2014.06.043 . hal-01064008

\section{HAL Id: hal-01064008 \\ https://hal.science/hal-01064008}

Submitted on 8 Oct 2014

HAL is a multi-disciplinary open access archive for the deposit and dissemination of scientific research documents, whether they are published or not. The documents may come from teaching and research institutions in France or abroad, or from public or private research centers.
L'archive ouverte pluridisciplinaire HAL, est destinée au dépôt et à la diffusion de documents scientifiques de niveau recherche, publiés ou non, émanant des établissements d'enseignement et de recherche français ou étrangers, des laboratoires publics ou privés. 
Reductive dehalogenation of 1,3-dichloropropane by a [Ni(tetramethylcyclam) $\mathrm{Br}_{2}-\mathrm{Nafion}^{\circledR}$ modified electrode

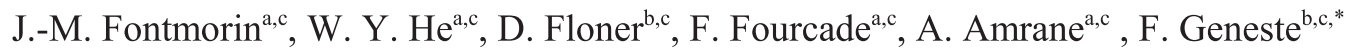

${ }^{a}$ Ecole Nationale Supérieure de Chimie de Rennes / Université de Rennes 1, CNRS, UMR 6226, 11 allée de Beaulieu, CS 50837, 35708 Rennes cedex 7, France.

${ }^{\mathrm{b}}$ Université de Rennes 1, CNRS, UMR 6226, Equipe Matière Condensée et Systèmes Electroactifs, Campus de Beaulieu, 35042 Rennes cedex, France.

${ }^{\mathrm{c}}$ Université Européenne de Bretagne, 5 boulevard Laënnec, 35000 Rennes, France.

\section{Abstract}

Dechlorination reaction of 1,3-dichloropropane, a contaminant solvent, was investigated by electrochemical reduction in aqueous medium using a $\mathrm{Ni}(\mathrm{tmc}) \mathrm{Br}_{2}$ complex, known as effective catalyst in dehalogenation reactions. The catalytic activity of the complex was first investigated by cyclic voltammetry and flow homogeneous redox catalysis using a graphite felt as working electrode. A total degradation of 1,3-dichloropropane was obtained after $5 \mathrm{~h}$ of electrolysis with a substrate/catalyst ratio of 2.3. The concentration of chloride ions determined by ion chromatography analysis showed a dechlorination yield of $98 \%$. The complex was then immobilized on the graphite felt electrode in a Nafion ${ }^{\circledR}$ film. Flow heterogeneous catalytic reduction of 1,3-dichloropropane was then carried out with the $[\mathrm{Ni}(\mathrm{tmc})] \mathrm{Br}_{2}$-modified Nafion ${ }^{\circledR}$ electrode. GC analyses underlined the total degradation of the substrate in only $3.5 \mathrm{~h}$ with a substrate/catalyst ratio of 100 . A dechlorination yield of $80 \%$ was obtained, as seen with ion chromatography analyses of chloride ion. Comparison of both homogeneous and heterogeneous reactions highlighted the interest of the $[\mathrm{Ni}(\mathrm{tmc})] \mathrm{Br}_{2}-$ modified Nafion ${ }^{\circledR}$ electrode that led to a higher stability of the catalyst with a turnover number of 180 and a higher current efficiency.

Keywords: dechlorination, redox catalysis, modified electrode, Ni-cyclam, chlorinated solvent

\section{Introduction}

Chlorinated compounds are the most frequently observed contaminants in grounds and groundwaters due to their high use as solvents and degreasers. Pollutions by chlorinated

Corresponding author. E-mail address: Florence.Geneste@univ-rennes1.fr 
solvents are often associated with paint and metal industries or with small companies, such as garages, printing offices and dry cleaning shops. Since they are characterized by a density higher than water, they penetrate the full depth of the aquifer and accumulate within its bottom. Chlorinated solvents are difficult to eliminate because they are generally nonbiodegradable, and destructive methods such as incineration are very expensive and can produce more toxic by-products like dioxins [1].

As a general point, electrocatalytic abatement of volatile organic compounds (VOCs) has been investigated by anodic oxidation on precious metals such as $\mathrm{Pt}$ [2-4] and by photoelectrocatalytic systems [5]. A few articles deal also with electroreduction of VOCs for dechlorination on $\mathrm{Ag}, \mathrm{Au}$ and $\mathrm{Cu}$ in dimethylformamide [6-8].

Since halogenated hydrocarbons are in an oxidized state relative to their non-halogenated derivatives, methods based on reduction of halocarbons have been developed for chlorinated solvents degradation [9-13]. Electrochemical reduction has the advantage to be a controllable method, allowing a selective reduction into completely dehalogenated chemical species. Working electrodes of different nature such as metals, carbon and conductive ceramics have been studied to achieve this goal [14-17]. Indirect electrolyses that involve a molecular catalyst/mediator are particularly attractive since they allow selective electrochemical reductions at less cathodic potentials than direct electrolyses, thus reducing energy consumption. The electrochemical reductions of carbon-halogen bonds in the presence of a catalyst/mediator have been widely studied in organic media [18], while only few studies have been performed in aqueous media [19-23].

Nickel(I)-cyclam (1,4,8,11-tetraazacyclotetra-decane)nickel(I)) derivatives are well-known for their catalytic activity towards dehalogenation reactions [24, 25]. More recently, $[\mathrm{Ni}(\mathrm{tmc})]^{+} \quad(1,4,8,11$-tetramethyl-1,4,8,11-tetraazacyclotetra-decane)nickel(I), prepared by electrochemical reduction of $\mathrm{Ni}(\mathrm{tmc}) \mathrm{Br}_{2}$ has shown its efficiency for the reduction of bromo alkyl compounds in hydroalcoholic medium [21, 22, 26-28].

The dehalogenation reaction in the presence of $\mathrm{Ni}(\mathrm{tmc}) \mathrm{Br}_{2}$, of a chlorinated alkyl compound, 1,3-dichloropropane, that has been detected as contaminant in source water [29] was therefore investigated in this work. The immobilization of the complex onto a graphite felt electrode was achieved by polymer coatings using $\mathrm{Nafion}^{\circledR}$, a perfluorinated anionic polyelectrolyte which exhibits permselectivity towards cations. The catalytic activity of the immobilized complex was first investigated by cyclic voltammetry analyses. Electrolyses of 1,3dichloropropane were then performed on the $\mathrm{Ni}(\mathrm{tmc}) \mathrm{Br}_{2}$-modified Nafion ${ }^{\circledR}$ electrode in a flow electrochemical cell. 


\section{Experimental}

\subsection{Reagents and materials}

Graphite felt was obtained from MERSEN (Paris La Defense, France). Its specific area measured by the BET method is $0.7 \mathrm{~m}^{2} \mathrm{~g}^{-1}$ and its density is $0.088 \mathrm{~g} \mathrm{~cm}^{-3}$. 1,3dichloropropane was purchased from ACROS and 5\% solution of Nafion ${ }^{\circledR} 117$ from Aldrich. [Ni(tmc) $] \mathrm{Br}_{2}$ (1,4,8,11-tetramethyl-1,4,8,11-tetraazacyclotetra-decane)nickel(I) dibromide) was prepared according to a literature procedure [30]. All solutions were prepared with ultrapure water (18.2 M 2 , Millipore Simplicity) and absolute ethanol (> 99.7\%) was purchased from VWR chemicals.

\subsection{Instrumentation}

Controlled potential electrolyses were performed in a divided flow cell, fitted with a graphite felt electrode (10 mm diameter, $12 \mathrm{~mm}$ thickness) located between two counter electrodes (Fig. 1) [31, 32].

\section{Figure 1}

Two cationic exchange membranes (Ionac MC 3470 from Nicou environnement, France) were used for cell division. The reference electrode (Saturated Calomel Electrode, SCE, purchased from Radiometer analytical) was positioned at an equal distance from the entry and the exit of the porous electrode. Voltammetric experiments were carried out using an EDAQ potentiostat unit, with the EChem software package. A platinum wire working electrode, a platinum wire auxiliary electrode, and a saturated calomel reference electrode were used in a standard three-electrode configuration. The graphite felt sample $\left(\sim 1 \mathrm{~cm}^{3}\right)$ was fixed to the platinum wire before analysis. Cyclic voltammetry analyses of immobilized complexes were performed under a dinitrogen atmosphere.

Analysis of chloride ions was performed with a DIONEX DX-120 ion chromatography equipped with a DIONEX AS19 $(4 \times 250 \mathrm{~mm})$ ion-exclusion column. Potassium hydroxide was used as eluant and the flow rate was $1 \mathrm{~mL} \min ^{-1}$. The detection was carried out by conductivity with a Self Regenerating Suppressor (ASRS ${ }^{\circledR}$-Ultra II $4 \mathrm{~mm}$ ).

GC/FID analyses of 1,3-dichloropropane were performed using a Varian CP-3380 GC equipped with a GC-CP-Chiral-Dex column. Injector temperature: $200^{\circ} \mathrm{C}$ (pulsed split mode), 
FID detector temperature: $220^{\circ} \mathrm{C}$, oven temperature: $50^{\circ} \mathrm{C}$, pressure: 15 psi. The retention time of 1,3-dichloropropane was $4.5 \mathrm{~min}$ in these conditions.

TOC was measured by means of a TOC- $\mathrm{V}_{\mathrm{CPH} / \mathrm{CPN}}$ Total Organic Analyzer Schimadzu. Organic carbon compounds were combusted and converted to $\mathrm{CO}_{2}$, which was detected and measured by a non-dispersive infrared detector (NDIR), TOC values were always obtained using the standard NPOC (Non Purgeable Organic Carbon) method.

\subsection{Modification of the electrodes}

Glassy Carbon electrode

$50 \mu \mathrm{L}$ of a $5 \%$ solution of $\mathrm{Nafion}^{\circledR}$ were added to $450 \mu \mathrm{L}$ of absolute ethanol. $3 \mathrm{mg}$ of $[\mathrm{Ni}(\mathrm{tmc})] \mathrm{Br}_{2}$ were then solubilized in the Nafion ${ }^{\circledR}$ solution using an ultrasonic bath. $10 \mu \mathrm{L}$ of this solution were deposited on the electrode surface and air-dried at air. The modified electrode was dipped in $0.1 \mathrm{M} \mathrm{Na}_{2} \mathrm{SO}_{4}$ under stirring overnight. Before use, the electrode was air-dried and carefully washed with distilled water.

Graphite felt electrode

$800 \mu \mathrm{L}$ of a $5 \%$ solution of Nafion ${ }^{\circledR}$ were added to $4.2 \mathrm{~mL}$ of absolute ethanol. $20 \mathrm{mg}$ of $[\mathrm{Ni}(\mathrm{tmc})] \mathrm{Br}_{2}$ were then solubilized in the Nafion ${ }^{\circledR}$ solution using an ultrasonic bath. The graphite felt was dipped in the solution for $30 \mathrm{~min}$, pressed and air-dried overnight. The modified graphite felt was then washed with water and dipped in $0.1 \mathrm{M} \mathrm{Na}_{2} \mathrm{SO}_{4}$.

\subsection{Flow electroreduction of 1,3-dichloropropane}

Flow electrolyses were carried out in the flow electrochemical cell (Fig. 1) with a fresh graphite felt or a $[\mathrm{Ni}(\mathrm{tmc})] \mathrm{Br}_{2}$-modified $\mathrm{Nafion}^{\circledR}$ electrode $(10 \mathrm{~mm}$ diameter, $12 \mathrm{~mm}$ thickness) at a potential of $-1.1 \mathrm{~V} / \mathrm{SCE}$ in $21 \mathrm{~mL}$ of a hydroalcoholic medium or water. All the flasks were closed to avoid evaporation of 1,3-dichloropropane and the electrolyte flowed through the porous electrode with recycling (flow rate: $1 \mathrm{~mL} \mathrm{~min}{ }^{-1}$ ). The concentration of catalyst and substrate are given in the text.

\section{Results and discussion}

\subsection{Cyclic voltammetry analyses}


The catalytic activity of the active form of the catalyst $[\mathrm{Ni}(\mathrm{tmc})]^{+}$toward the reduction of 1,3dichloropropane was first studied by cyclic voltammetry in ethanol since 1,3-dichloropropane is well soluble in this medium. The cyclic voltammogram of 1,3-dichloropropane (Fig. 2) in ethanol did not show any signal, corresponding to the 4 electrons reduction of the two $\mathrm{C}-\mathrm{Cl}$ bonds (Eq. 1).

$\mathrm{R}-\mathrm{X}+2 \mathrm{e}^{-} \rightarrow \mathrm{R}^{-}+\mathrm{X}^{-}$

The complex presented a reversible system corresponding to $\mathrm{Ni}^{\mathrm{II} / \mathrm{I}}$ at $-0.9 \mathrm{~V} / \mathrm{SCE}$ (Fig. 2).

Figure 2

Successive additions of 1,3-dichloropropane led to an enhancement of the reduction peak ( $\mathrm{Ni}^{\mathrm{II}}$ to $\mathrm{Ni}^{\mathrm{I}}$ ), while the reverse anodic peak decreased significantly and was totally suppressed for concentrations higher than $100 \mathrm{mM}$ (Fig. 2). These results underlines the catalytic activity of the $\mathrm{Ni}^{\mathrm{I}}$ complex toward the reduction of 1,3-dichloropropane that is known to reduce halogen bonds via an inner sphere mechanism (Eq. 2 and 3) [22].

$4\left[\mathrm{Ni}^{\mathrm{II}}(\mathrm{tmc})\right]^{2+}+4 \mathrm{e}^{-} \rightarrow 4\left[\mathrm{Ni}^{\mathrm{I}}(\mathrm{tmc})\right]^{+}$

$4\left[\mathrm{Ni}^{\mathrm{I}}(\mathrm{tmc})\right]^{+}+\mathrm{ClCH}_{2}-\mathrm{CH}_{2}-\mathrm{CH}_{2} \mathrm{Cl}+2 \mathrm{H}^{+} \rightarrow 4\left[\mathrm{Ni}^{\mathrm{II}}(\mathrm{tmc})\right]^{2+}+\mathrm{CH}_{3}-\mathrm{CH}_{2}-\mathrm{CH}_{3}+2 \mathrm{Cl}^{-}$

A detailed mechanism can be proposed based on literature [33], involving an oxidative addition of the substrate to the $\mathrm{C}-\mathrm{Cl}$ bond, followed by a reduction and a protonation by ethanol or water (Scheme 1).

However, according to cyclic voltammetry, the reaction seems to be slower than for propargyloxy $\alpha$-bromoester derivatives that contain a carbon in $\alpha$ of an ester group and exhibit a high catalytic effect with a substrate/catalyst ratio of only 10 [27].

In aqueous medium, the reversible system corresponding to $\mathrm{Ni}^{\mathrm{II} / \mathrm{I}}$ appeared at a more cathodic potential of $-1.1 \mathrm{~V} / \mathrm{SCE}$ (Fig. 3).

Figure 3

An increase of the cathodic peak was observed for a $20 \mathrm{mM}$ solution of 1,3-dichloropropane, underlining the catalytic activity of $[\mathrm{Ni}(\mathrm{tmc})]^{+}$in water (Fig. 3a). Addition of ethanol was 
necessary to increase the concentration of 1,3-dichloropropane in the analytical medium due to its low solubility in water. The oxidation wave was totally suppressed for a $60 \mathrm{mM}$ solution of 1,3-dichloropropane in a hydroalcoholic medium (Fig. 3b).

\subsection{Homogeneous catalysis}

To confirm cyclic voltammetry analyses, cathodic reduction of 1,3-dichloropropane was performed at $-1.1 \mathrm{~V} / \mathrm{SCE}$ in aqueous medium in the presence of $[\mathrm{Ni}(\mathrm{tmc})] \mathrm{Br}_{2}$. The reaction was carried out in the flow electrochemical cell with recycling of the solution and with a substrate/catalyst ratio of 4.8 . The evolution of the conversion $\left(n_{t} / n_{0}\right.$ with $n_{0}$ and $n_{t}$ the number of moles of 1,3-dichloropropane initial and at the time t, respectively) and the electrolytic current during electrolysis are given in Fig. 4a.

Figure 4

The reaction was fast at the beginning and then slowed down with the decrease of substrate concentration in the medium, leading to a conversion of $90 \%$ after 5 h of electrolysis. A $100 \%$ conversion was achieved with a substrate/catalyst ratio of 2.3 (Fig. 4b).

Chloride ions were analyzed by ion chromatography and a concentration of $99 \mathrm{mg} \mathrm{L}^{-1}$ was measured (after subtraction of the concentration of chloride ions measured in the electrolyte medium containing 1,3-dichloropropane before electrolysis), corresponding to an almost total dechlorination of 1,3-dichloropropane ( $98 \%$ conversion to propane).

A current efficiency of $32.2 \%$ was estimated from the charge passed considering a 2 electrons reduction per $\mathrm{Cl}^{-}$and a total dechlorination. This low value can be explained by the competition with the water reduction at the potential of $-1.1 \mathrm{~V} / \mathrm{SCE}$. The turnover number (around 4.5) was similar to other values given in literature for redox catalysis involving this complex $[33,34]$. Based on these promising results, redox catalysis with $[\mathrm{Ni}(\mathrm{tmc})] \mathrm{Br}_{2}$ complex immobilized on the graphite felt was then investigated.

\subsection{Immobilization of [Ni(tmc)]Br $r_{2}$ on the graphite felt electrode}

The complex was first immobilized on a Glassy Carbon electrode by incorporation into a Nafion $^{\circledR}$ film. The Nafion ${ }^{\circledR}$ ion-exchange polymer was chosen for its mechanical stability along with its high proton conductivity. To prepare the modified electrode, $10 \mu \mathrm{L}$ of a Nafion $^{\circledR}$ solution containing the complex $\left(600 \mathrm{mg} \mathrm{L}^{-1}\right)$ were deposited on the electrode 
surface. After drying, the electrode was analyzed by cyclic voltammetry. A dilution of the Nafion ${ }^{\circledR}$ solution to 0.5 wt. \% was necessary to obtain a well-defined reversible system in cyclic voltammetry (Fig. 5).

Figure 5

Comparison with the complex analyzed in solution showed that the half-wave potential of $\mathrm{Ni}^{\mathrm{iI} / \mathrm{I}}$ couple was similar before and after immobilization of the complex. The surface concentration of the immobilized complex was roughly estimated (Eq. 1 and 2) by integration of the peak using the Faraday law and was around $1.1 \pm 0.2 \times 10^{-8} \mathrm{~mol} \mathrm{~cm}^{-2}$.

$$
\begin{aligned}
\mathrm{Q} & =\mathrm{nF}=\mathrm{S} / \mathrm{v} \\
\tau_{\mathrm{s}} & =\mathrm{n} / \mathrm{s}
\end{aligned}
$$

with $\mathrm{Q}$ the electric charge (C), $\mathrm{n}$ the number of moles of immobilized catalyst (mol), $\mathrm{F}$ the Faraday constant $96485 \mathrm{C} \mathrm{mol}^{-1}, \mathrm{~S}$ the surface area of the peak (A V), v the scan rate $\left(\mathrm{V} \mathrm{s}^{-1}\right)$, $\mathrm{s}$ the electrode surface $\left(\mathrm{cm}^{-2}\right)$ and $\tau_{\mathrm{s}}$ the surface concentration $(\mathrm{mol} \mathrm{cm})$.

The optima conditions used to prepare the $[\mathrm{Ni}(\mathrm{tmc})] \mathrm{Br}_{2}$ modified $\mathrm{Nafion}{ }^{\circledR}$ electrode were then applied to the modification of the graphite felt electrode. For the deposition step, a felt of 1 $\mathrm{cm}^{3}$ was dipped in the Nafion ${ }^{\circledR}$ solution containing the complex for $30 \mathrm{~min}$, pressed and airdried overnight. Cyclic voltammetry analyses were performed after one or three successive depositions of Nafion ${ }^{\circledR}$ on the graphite felt according to this method (Fig. 6a).

Figure 6

The reversible system corresponding to the $\mathrm{Ni}^{\mathrm{II} / \mathrm{I}}$ couple was less well-defined after three baths, showing the presence of a blocking film on the electrode surface. One bath was therefore considered thereafter for the modification of the graphite felt. We also noticed that the electrochemical response was dependent on the solvent used for the analysis: the electrochemical signal was slightly higher in hydroalcoholic solution than in water (Fig. 6b). This behavior is probably due to the hydrophobic character of Nafion. A volume concentration of $3.1 \pm 0.8 \times 10^{-7} \mathrm{~mol} \mathrm{~cm}^{-3}$ of immobilized catalyst was estimated (Eq. 1 and 3) from cyclic voltammetry performed in hydroalcoholic medium using the Faraday law. This value was deduced from the analysis of 9 modified electrodes. 


$$
\tau_{\mathrm{v}}=\mathrm{n} / \mathrm{V}
$$

with $\mathrm{n}$ the number of moles of immobilized catalyst (mol), $\mathrm{V}$ the electrode volume $\left(\mathrm{cm}^{-3}\right)$ and $\tau_{\mathrm{v}}$ the volume concentration $\left(\mathrm{mol} \mathrm{cm} \mathrm{cm}^{-3}\right)$.

The $[\mathrm{Ni}(\mathrm{tmc})] \mathrm{Br}_{2}$ modified Nafion ${ }^{\circledR}$ electrode was analyzed by Scanning Electron Microscopy (Fig. 7)

Figure 7

As seen in Fig. 7b, the presence of an organic film on the graphite fibers was clearly highlighted compared with the fresh graphite felt (Fig. 7a) and with Nafion-enriched regions (Fig. $7 \mathrm{c}$ and d). The deposition of the polymer seems to be well distributed inside the felt without blocking the porosity, which is in accordance with the good reproducibility of the surface concentration measurements.

The catalytic activity of the modified graphite felt toward the reduction of 1,3dichloropropane was studied by cyclic voltammetry in hydroalcoholic medium, to avoid the problem of the low solubility of the substrate in water (Fig. 8).

Figure 8

An increase of the cathodic peak was observed in a $20 \mathrm{mM}$ solution of 1,3-dichloropropane and the oxidation wave was totally suppressed for a $100 \mathrm{mM}$ solution. No difference in behavior was therefore shown between the catalyst in solution and after immobilization on the electrode surface.

\subsection{Dechlorination reaction using the $[\mathrm{Ni}(\mathrm{tmc})] \mathrm{Br}_{2}-\mathrm{Nafion}{ }^{\circledR}$ modified electrode}

The cathodic reduction of 1,3-dichloropropane $\left(2.3 \times 10^{-3} \mathrm{~mol} \mathrm{~L}^{-1}\right)$ was carried out at -1.1 $\mathrm{V} / \mathrm{SCE}$ in the flow electrochemical cell with recycling of the solution (flow rate: $1 \mathrm{~mL} \mathrm{~min}^{-1}$ ). A blank was first performed with a bare graphite felt as a working electrode. The conversion and the electrolytic current were followed by gas chromatography (Fig. 9a).

Figure 9 
No significant degradation of 1,3-dichloropropane was noticed, showing that the substrate cannot be reduced without catalyst at this potential. The presence of an electrolytic current (-2 $\mathrm{mA}$ ) was due to the reduction of water that already occurs at $-1.1 \mathrm{~V} / \mathrm{SCE}$ (Eq. 1).

$\mathrm{H}_{2} \mathrm{O}+\mathrm{e}-\rightarrow 1 / 2 \mathrm{H}_{2}+\mathrm{OH}^{-}$

This gives rise to a $\mathrm{pH}$ increase during the reaction, leading to a cathodic shift of the potential corresponding to hydrogen evolution and consequently to a decrease of the electrolytic current. The cathodic reduction of 1,3-dichloropropane $\left(1.4 \times 10^{-3} \mathrm{~mol} \mathrm{~L}^{-1}\right)$ was then performed in the same conditions on a $[\mathrm{Ni}(\mathrm{tmc})] \mathrm{Br}_{2}$-modified $\mathrm{Nafion}^{\circledR}$ electrode (substrate/catalyst ratio of 100). A rapid degradation of the substrate was observed with a conversion of $96 \%$ after $2 \mathrm{~h}$ (Fig. $9 \mathrm{~b}$ ).

The cathodic reduction of 1,3-dichloropropane $\left(1.4 \times 10^{-3} \mathrm{~mol} \mathrm{~L}^{-1}\right)$ was then performed in the same conditions except that the hydroalcoholic solution was replaced by water. A $100 \%$ conversion was obtained in $3.5 \mathrm{~h}$ (Fig. 9c), showing that the reaction can also be achieved in aqueous medium. The analysis of chloride ions by ion chromatography revealed a dechlorination of 1,3-dichloropropane with a conversion to propane of $80 \%$.

It is noteworthy that a substrate/catalyst ratio of 2.3 was necessary to totally degrade 1,3dichloropropane when the catalyst was in solution, while this ratio increased to 100 with the $[\mathrm{Ni}(\mathrm{tmc})] \mathrm{Br}_{2}$ modified Nafion ${ }^{\circledR}$ electrode for a total conversion of 1,3-dichloropropane. A turnover of 180 can be calculated from the dechlorination yield, whereas it was only 4.5 in homogeneous catalysis. These results underline the interest of the flow heterogeneous catalysis for which only a low amount of catalyst is necessary. A current efficiency of $43.5 \%$ was calculated from the charge passed considering $80 \%$ dechlorination, showing again a competition reaction with water reduction.

\subsection{Stability of the $[\mathrm{Ni}(\mathrm{tmc})] \mathrm{Br}_{2}$-modified Nafion ${ }^{\circledR}$ electrode}

Cyclic voltammetry analysis of the $[\mathrm{Ni}(\mathrm{tmc})] \mathrm{Br}_{2}$-modified Nafion ${ }^{\circledR}$ electrode performed after electrolysis showed a decrease of the electrochemical signal corresponding to the $\mathrm{Ni}^{\mathrm{II} / \mathrm{I}}$ system (Fig. 10a).

Figure 10 
To get inside information on the stability, the electrolyte solution without 1,3-dichloropropane was percolated through the modified electrode at open circuit. The electrochemical signal remained stable after $3 \mathrm{~h}$ (Fig. 10b), showing the absence of mechanical leaching of the catalyst in the solution. These results were corroborated by TOC measurements of the solution. The TOC values were similar when the electrolyte solution flowed through a fresh graphite felt or a $[\mathrm{Ni}(\mathrm{tmc})] \mathrm{Br}_{2}$-modified Nafion ${ }^{\circledR}$ electrode $(\Delta \mathrm{TOC}=0.6)$.

On the one hand total leaching of the catalyst in solution should lead to an increase of the TOC value of only $1.7 \mathrm{mg} \mathrm{L}^{-1}$, and on the other hand these experiments should also allow to investigate the degradation of the graphite felt electrode during electrolysis. Thus, electrolyses were performed on modified and unmodified graphite felt and the difference of TOC before and after catalysis are given in Table 1 . The value of $\triangle \mathrm{TOC}$ remained low for electrolyses performed without 1,3-dichloropropane, whereas it highly increased when the reduction was carried out in the presence of the substrate. Since the only sources of carbon that can lead to such increase of $\triangle \mathrm{TOC}$ were the graphite felt electrode and the Nafion ${ }^{\circledR}$ polymer, it seemed that there was a degradation of the electrode during the electroreduction of 1,3dichloropropane. Whereas a mechanism involving an oxidative addition of the substrate on the complex has been previously proposed to explain the catalytic activity of $[\mathrm{Ni}(\mathrm{tmc})] \mathrm{Br}_{2}$ [34], a possible explanation would be the formation of radical intermediates during the electrochemical reduction of 1,3-dichloropropane that would attack the electrode causing its degradation.

\section{Conclusions}

In conclusion, the cathodic reduction of a chlorinated solvent was performed by redox catalysis using a $[\mathrm{Ni}(\mathrm{tmc})] \mathrm{Br}_{2}$-modified $\mathrm{Nafion}^{\circledR}$ electrode. The catalytic activity of the complex toward the reduction of 1,3-dichloropropane was first checked by cyclic voltammetry, showing that the kinetic of the catalytic reaction is slow. A good mechanical stability of the modified graphite felt was shown by cyclic voltammetry and TOC measurements. The reductive dechlorination reaction was almost total, as outlined by ion chromatography analysis of chloride ions. Comparison of homogeneous and heterogeneous catalysis highlighted a higher stability of the catalyst giving rise to a higher turnover number and a better current efficiency. An increase of the TOC value was noticed after homogeneous and heterogeneous catalyses in the presence of 1,3-dichloropropane, that can be explained by the formation of radical intermediates in the catalytic cycle. 


\section{Acknowledgements}

We gratefully acknowledge Dominique Paris for the fabrication of the electrochemical flow cell and for the Solidworks image.

\section{References}

[1] T. Shibamoto, A. Yasuhara, T. Katami, Dioxin formation from waste incineration, Springer, New York, 2007.

[2] R. J. Isaifan, E. A. Baranova, Electrochem. Commun. 27 (2013) 164.

[3] A. Piram, X. Li, F. Gaillard, C. Lopez, A. Billard, P. Vernoux, lonics 11 (2005) 327.

[4] L. Wang, T. P. Tran, D. V. Vo, M. Sakurai, H. Kameyama, Appl. Catal. A-Gen. 350 (2008) 150.

[5] H.-S. Kim, E.-A. Lee, J.-H. Lee, C.-H. Han, J.-W. Ha, Y.-G. Shul, Int. J. Photoenergy 5 (2003) 3.

[6] B. Huang, A. A. Isse, C. Durante, C. Wei, A. Gennaro, Electrochimica Acta 70 (2012) 50.

[7] C. Durante, B. Huang, A. A. Isse, A. Gennaro, Appl. Catal. B-Environ. 126 (2012) 355.

[8] A. A. Isse, B. Huang, C. Durante, A. Gennaro, Appl. Catal. B-Environ. 126 (2012) 347.

[9] F. Fu, D. D. Dionysioub, H. Liu, J. Hazard. Mater. 267 (2014) 194.

[10] W. W. J. McNab, R. Ruiz, Chemosphere 37 (1998) 925.

[11] T. Li, J. Farrell, Environ. Sci. Technol. 34 (2000) 173.

[12] J. He, W. P. Ela, E. A. Betterton, R. G. Arnold, A. E. Saez, Ind. Eng. Chem. Res. 43 (2004) 7965.

[13] D. F. Laine, I. F. Cheng, Microchem. J. 85 (2007) 183.

[14] S. M. Kulikov, V. P. Plekhanov, A. I. Tsyganok, C. Schlimm, E. Heitz, Electrochim. Acta 41 (1996) 527.

[15] C. S. Criddle, P. L. McCarty, Environ. Sci. Technol. 25 (1991) 973.

[16] I. F. Cheng, Q. Fernando, N. Korte, Environ. Sci. Technol. 31 (1997) 1074.

[17] G. Chen, E. A. Betterton, R. G. Arnold, J. Appl. Electrochem. 29 (1999) 961.

[18] H. Lund, O. Hammerich, Organic electrochemistry, M. Dekker, Inc., New York, 2001.

[19] D.-L. Zhou, H. Carrero, J. F. Rusling, Langmuir 12 (1996) 3067.

[20] G. Muthuraman, K. Chandrasekarapillai, J. Colloid Interface Sci. 297 (2006) 687. 
[21] E. Dunach, M. J. Medeiros, S. Olivero, J. Electrochem. Soc. 160 (2013) G3112.

[22] M. J. Medeiros, C. S. S. Neves, A. R. Pereira, E. Dunach, Electrochim. Acta 56 (2011) 4498.

[23] F. Raynal, R. Barhdadi, J. Périchon, A. Savall, M. Troupel, Adv. Synth. Catal. 344 (2002) 45.

[24] S. Olivero, J.-P. Rolland, E. Dunach, Organometallics 17 (1998) 3747.

[25] A. P. Esteves, A. M. Freitas, M. J. Medeiros, D. Pletcher, J. Electroanal. chem. 499 (2001) 95.

[26] T. A. Dias, C. Durães, A. P. Esteves, M. J. Medeiros, D. Pletcher, ECS Trans. 19 (11) (2009) 1.

[27] X. Chaminade, E. Dunach, A. P. Esteves, M. J. Medeiros, C. S. Neves, S. Olivero, Electrochim. Acta 54 (2009) 5120-5126.

[28] E. Dunach, M. J. Medeiros, Electrochim. Acta 53 (2008) 4470.

[29] R. Tornero-Velez, M. K. Ross, C. Granville, J. Laskey, J. P. Jones, D. M. DeMarini, M. V. Evans, Drug Metab. Dispos. 32 (2004) 123.

[30] B. Bosnich, M. L. Tobe, G. A. Webb, Inorg. Chem. 4 (1965) 1109.

[31] F. Geneste, M. Cadoret, C. Moinet, G. Jezequel, New J. Chem. 26 (2002) 1261.

[32] C. Moinet, J. Phys. IV 4 (1994) 175.

[33] E. Dunach, A. P. Esteves, M. J. Medeiros, C. S. dos Santos Neves, S. Olivero, C. R. Chimie 12 (2009) 889.

[34] E. Dunach, A. P. Esteves, M. J. Medeiros, S. Olivero, Green Chem. 8 (2006) 380.

Table 1: TOC after electrolysis - TOC before electrolysis by flowing the solution through the graphite felt (GF) with recycling

\begin{tabular}{|c|c|c|c|}
\hline \multicolumn{3}{|l|}{ Experimental conditions } & \multirow[t]{2}{*}{$\Delta \mathrm{TOC} / \mathrm{mg} \mathrm{L}^{-1}$} \\
\hline Electrodes & Solution & Time/h & \\
\hline Bare GF & $\begin{array}{l}0.1 \mathrm{M} \mathrm{Na}_{2} \mathrm{SO}_{4} \\
\text { 1,3-dichloropropane }\left(1.4 \times 10^{-3} \mathrm{~mol} \mathrm{~L}^{-1}\right) \\
{[\mathrm{Ni}(\mathrm{tmc})] \mathrm{Br}_{2}\left(7 \times 10^{-4} \mathrm{~mol} \mathrm{~L}^{-1}\right)}\end{array}$ & 5 & $53 \pm 12$ \\
\hline$[\mathrm{Ni}(\mathrm{tmc})] \mathrm{Br}_{2}$-modified GF & $0.1 \mathrm{M} \mathrm{Na}_{2} \mathrm{SO}_{4}$ & 7 & $4 \pm 2$ \\
\hline$[\mathrm{Ni}(\mathrm{tmc})] \mathrm{Br}_{2}$-modified GF & $\begin{array}{l}0.1 \mathrm{M} \mathrm{Na}_{2} \mathrm{SO}_{4} \\
\text { 1,3-dichloropropane }\left(1.4 \times 10^{-3} \mathrm{~mol} \mathrm{~L}^{-1}\right)\end{array}$ & 7 & $18 \pm 6$ \\
\hline
\end{tabular}

Figure and Scheme captions

Scheme 1: Mechanism proposed for the catalytic reduction of 1,3-dichloroproane 
Figure 1: Flow electrochemical cell used for electrolysis

Figure 2: Cyclic voltammograms of $100 \mathrm{mM}$ 1,3-dichloropropane (..) and $[\mathrm{Ni}(\mathrm{tmc})] \mathrm{Br}_{2}$ complex $(2 \mathrm{mM})$ in ethanol $+\mathrm{Bu}_{4} \mathrm{NBr} 0.1 \mathrm{M}$ before $(-)$ and after addition of 1,3dichloropropane at $20 \mathrm{mM}(\ldots . .),. 60 \mathrm{mM}(----), 100 \mathrm{mM}(--.-)$ and $200 \mathrm{mM}(-)$ on GC electrode $\left(7 \mathrm{~mm}^{2}\right)$ at $10 \mathrm{mV} \mathrm{s}^{-1}$.

Figure 3: a) Cyclic voltammograms of $[\mathrm{Ni}(\mathrm{tmc})] \mathrm{Br}_{2}$ complex $(2 \mathrm{mM})$ in water $+0.1 \mathrm{M}$ $\mathrm{Na}_{2} \mathrm{SO}_{4}$ before (-) and after addition of 1,3-dichloropropane at $20 \mathrm{mM}(----)$ b) Cyclic voltammograms of $[\mathrm{Ni}(\mathrm{tmc})] \mathrm{Br}_{2}$ complex $(2 \mathrm{mM})$ in $\mathrm{H}_{2} \mathrm{O} / \mathrm{EtOH}(90: 10)+0.1 \mathrm{M} \mathrm{Na}_{2} \mathrm{SO}_{4}$ before (-) and after addition of 1,3-dichloropropane at $60 \mathrm{mM}$ (----). Glassy Carbon electrode $\left(7 \mathrm{~mm}^{2}\right), 10 \mathrm{mV} \mathrm{s}^{-1}$.

Figure 4: Conversion ( $\bullet$ and electrolytic current (๘) versus electrolysis time for cathodic reduction performed on a graphite felt electrode at $-1.1 \mathrm{~V} / \mathrm{SCE}$ with recycling of the solution of 1,3-dichloropropane $\left(1.43 \times 10^{-3} \mathrm{~mol} \mathrm{~L}^{-1}\right)$ in a $0.1 \mathrm{M} \mathrm{Na}_{2} \mathrm{SO}_{4}$ aqueous solution with $[\mathrm{Ni}(\mathrm{tmc})] \mathrm{Br}_{2}$ a) $3 \times 10^{-4} \mathrm{~mol} \mathrm{~L}^{-1}$ b) $6.2 \times 10^{-4} \mathrm{~mol} \mathrm{~L}^{-1}$. Flow rate: $1 \mathrm{~mL} \mathrm{~min}^{-1}$

Figure 5: Cyclic voltammogram of $[\mathrm{Ni}(\mathrm{tmc})] \mathrm{Br}_{2}$ complex $(2 \mathrm{mM})$ in water $+0.1 \mathrm{M} \mathrm{Na}_{2} \mathrm{SO}_{4}$ on GC electrode (---) and on modified Glassy Carbon electrode (-). $20 \mathrm{mV} \mathrm{s}^{-1}$

Figure 6: a) Cyclic voltammogram of a fresh graphite felt (----) and of a $[\mathrm{Ni}(\mathrm{tmc})] \mathrm{Br}_{2}-\mathrm{Nafion}^{\circledR}$ modified graphite felt with one $\left(-\right.$ ) or three (…) baths in $\mathrm{H}_{2} \mathrm{O} / \mathrm{EtOH}(90: 10)+0.1 \mathrm{M}$ $\mathrm{Na}_{2} \mathrm{SO}_{4} .20 \mathrm{mV} \mathrm{s}^{-1}$ b) Cyclic voltammogram of a $[\mathrm{Ni}(\mathrm{tmc})] \mathrm{Br}_{2}-\mathrm{Nafion}^{\circledR}$ modified graphite felt in $\mathrm{H}_{2} \mathrm{O} / \mathrm{EtOH}(90: 10)+0.1 \mathrm{M} \mathrm{Na}_{2} \mathrm{SO}_{4}(-)$ and in $\mathrm{H}_{2} \mathrm{O}+0.1 \mathrm{M} \mathrm{Na}_{2} \mathrm{SO}_{4}(----) .20 \mathrm{mV} \mathrm{s}^{-1}$

Figure 7: SEM images of a) fresh graphite and b-d) Ni(tmc)] $\mathrm{Br}_{2}$-modified Nafion ${ }^{\circledR}$ electrode. Magnification a) and b) $\times 10000$, c) $\times 200$ and d) $\times 1000$.

Figure 8: Cyclic voltammetry of a $\left[\mathrm{Ni}\left(\mathrm{tmc}_{\mathrm{tmc}}\right) \mathrm{Br}_{2}\right.$-modified $\mathrm{Nafion}^{\circledR}$ electrode in $\mathrm{H}_{2} \mathrm{O} / \mathrm{EtOH}$ $(90: 10)+0.1 \mathrm{M} \mathrm{Na}_{2} \mathrm{SO}_{4}$ before (.....) and after addition of 1,3-dichloropropane at $20 \mathrm{mM}$ (--$--), 100 \mathrm{mM}(-)$.

Figure 9: Conversion ( $\bullet$ ) and electrolytic current (-) versus electrolysis time for cathodic reduction of 1,3-dichloropropane $\left(2.3 \times 10^{-3} \mathrm{~mol} \mathrm{~L}^{-1}\right)$ performed at $-1.1 \mathrm{~V} / \mathrm{SCE}$ in $\mathrm{H}_{2} \mathrm{O} / \mathrm{EtOH}$ $(90: 10)+0.1 \mathrm{M} \mathrm{Na}_{2} \mathrm{SO}_{4}$ (a) and for cathodic reduction of 1,3-dichloropropane $\left(1.4 \times 10^{-3} \mathrm{~mol}\right.$ 
$\mathrm{L}^{-1}$ ) performed at $-1.1 \mathrm{~V} / \mathrm{SCE}$ on a $[\mathrm{Ni}(\mathrm{tmc})] \mathrm{Br}_{2}-\mathrm{Nafion}{ }^{\circledR}$ modified graphite felt in $\mathrm{H}_{2} \mathrm{O} / \mathrm{EtOH}$ $(90: 10)+0.1 \mathrm{M} \mathrm{Na}_{2} \mathrm{SO}_{4}$ (b) and $0.1 \mathrm{M} \mathrm{Na}_{2} \mathrm{SO}_{4}(\mathrm{c}) \cdot\left(1 \mathrm{~mL} \mathrm{~min}^{-1}\right)$

Figure 10: Cyclic voltammogram of a $[\mathrm{Ni}(\mathrm{tmc})] \mathrm{Br}_{2}$-modified $\mathrm{Nafion}^{\circledR}$ electrode a) in $\mathrm{H}_{2} \mathrm{O} / \mathrm{EtOH}(90: 10)+0.1 \mathrm{M} \mathrm{Na}_{2} \mathrm{SO}_{4}$ before (----) and after $(-)$ 3h of cathodic reduction of 1,3-dichloropropane $\left(1.4 \times 10^{-3} \mathrm{~mol} \mathrm{~L}^{-1}\right)$ performed at -1.1 V/SCE $\left(1 \mathrm{~mL} \mathrm{~min}^{-1}\right)$ b) in $0.1 \mathrm{M}$ $\mathrm{Na}_{2} \mathrm{SO}_{4}$ before (-----) and after (-) flowing the electrolyte solution through the electrode for $3 \mathrm{~h}$ at open circuit. $20 \mathrm{mV} \mathrm{s}^{-1}$.

Scheme 1

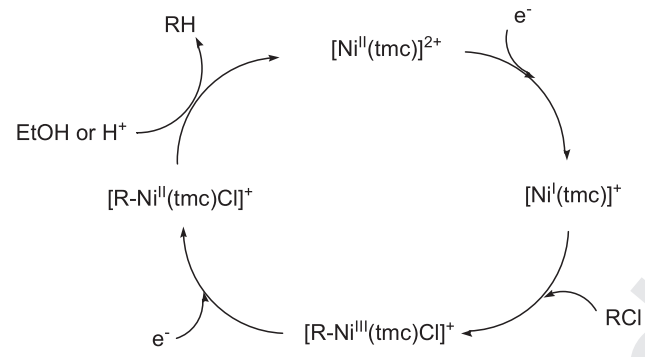

Figure 1 


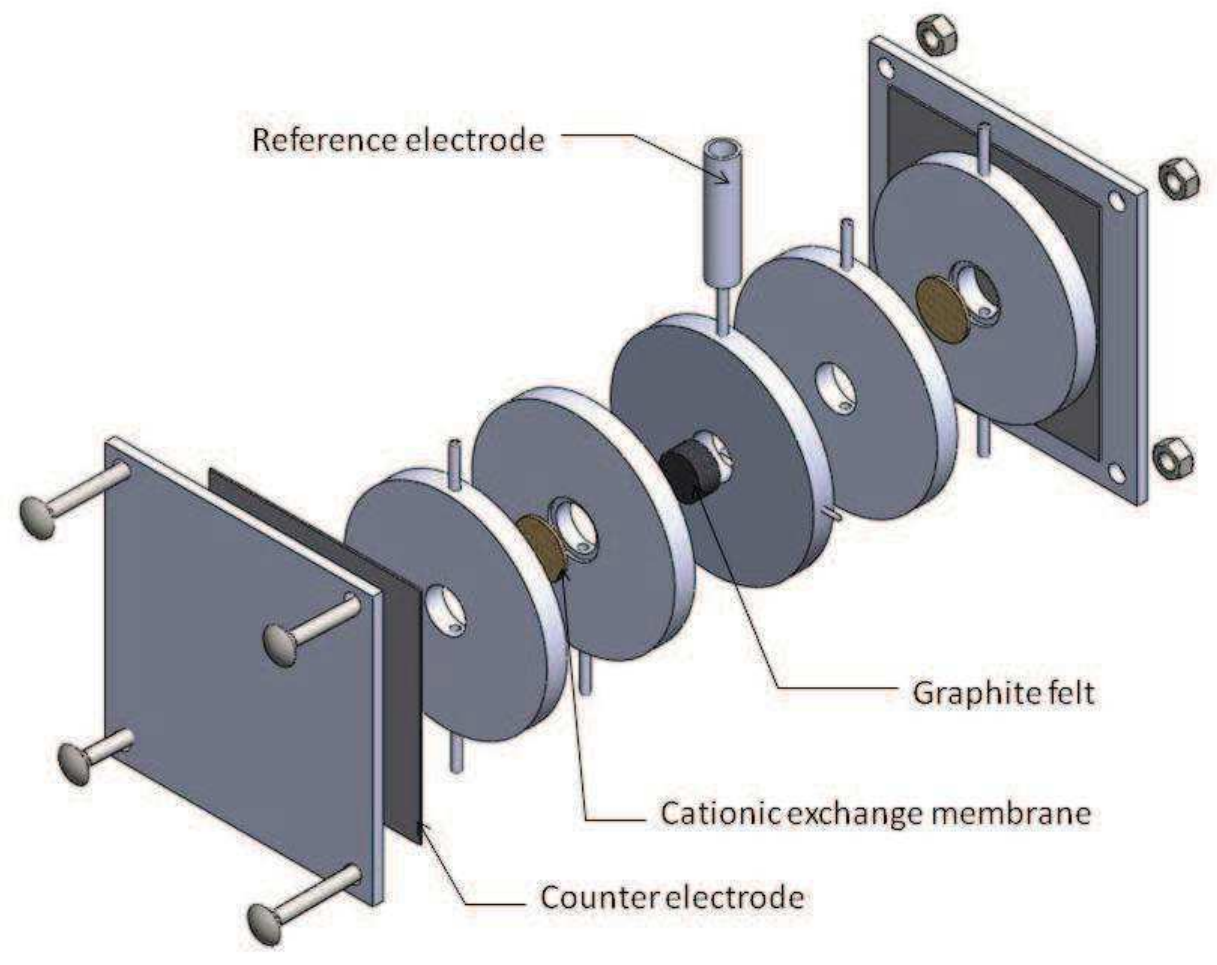


Figure 2

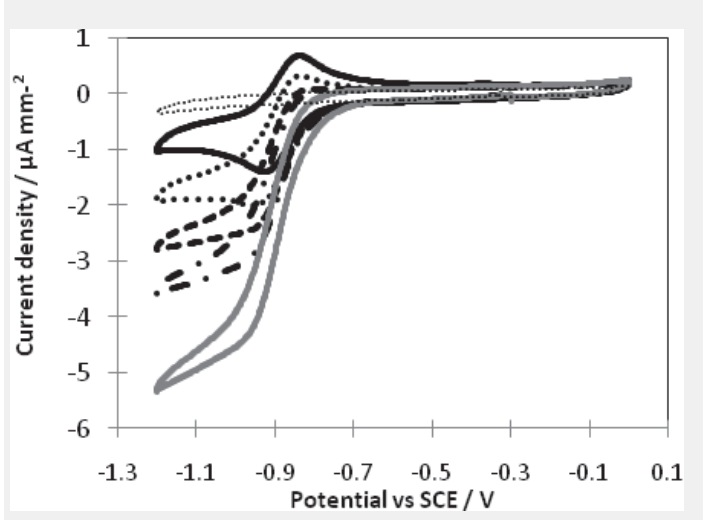


Figure 3

a)

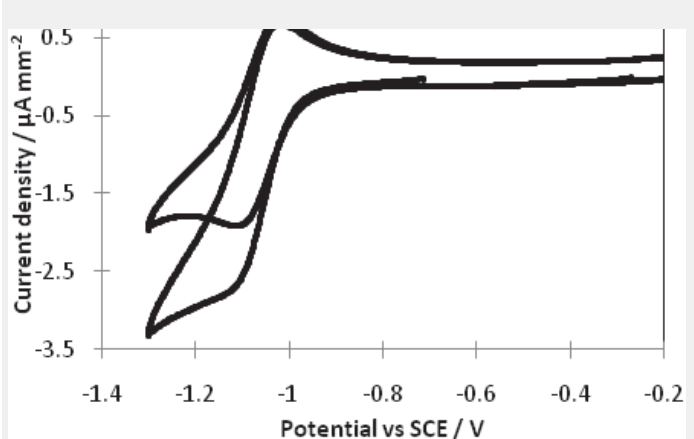

b)

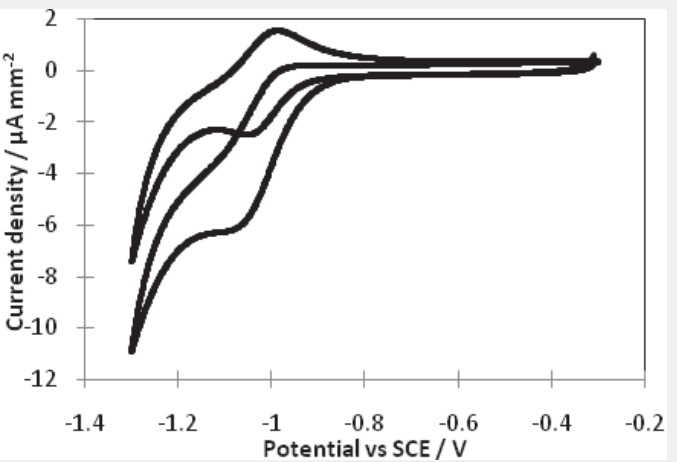


Figure 4

a)

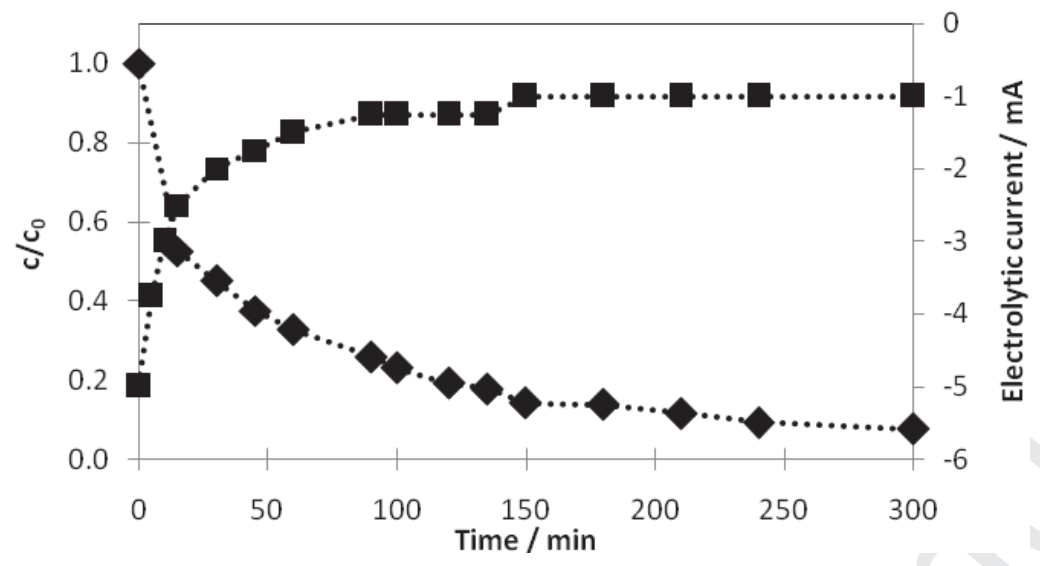

b)

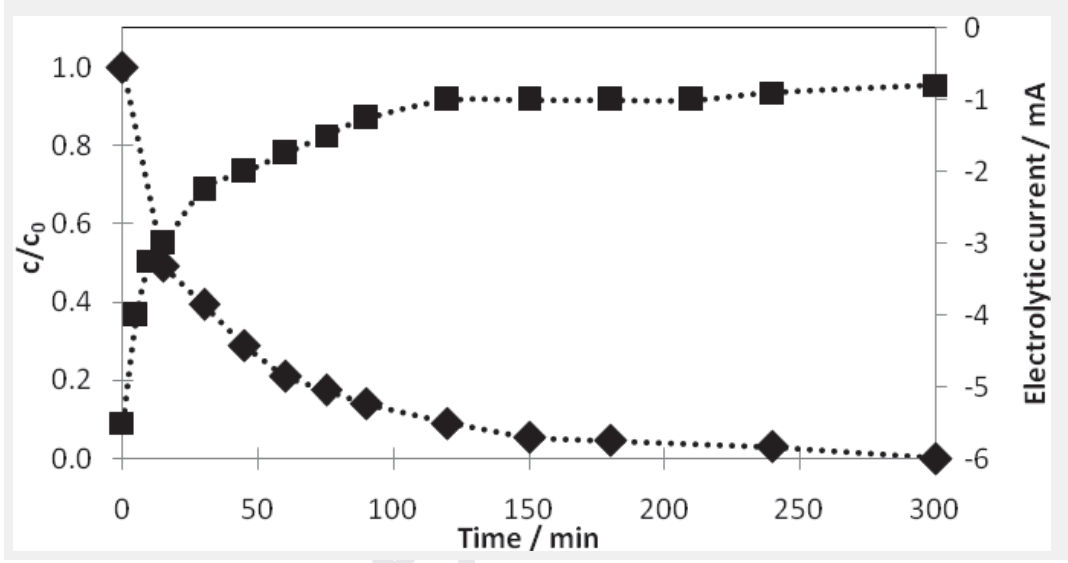


Figure 5

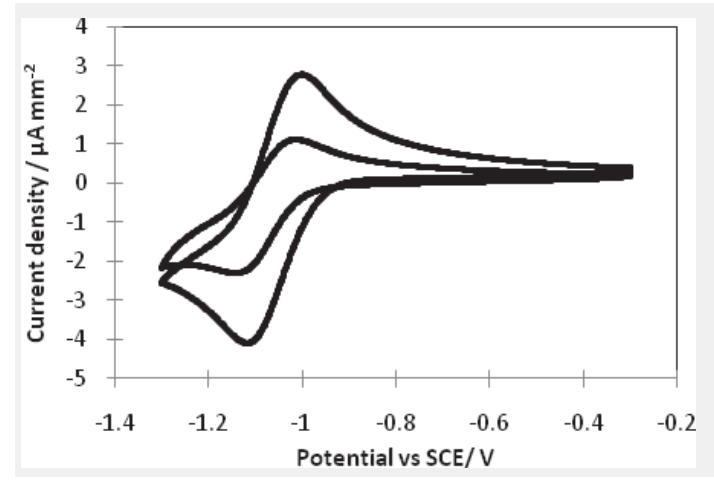


Figure 6

a)

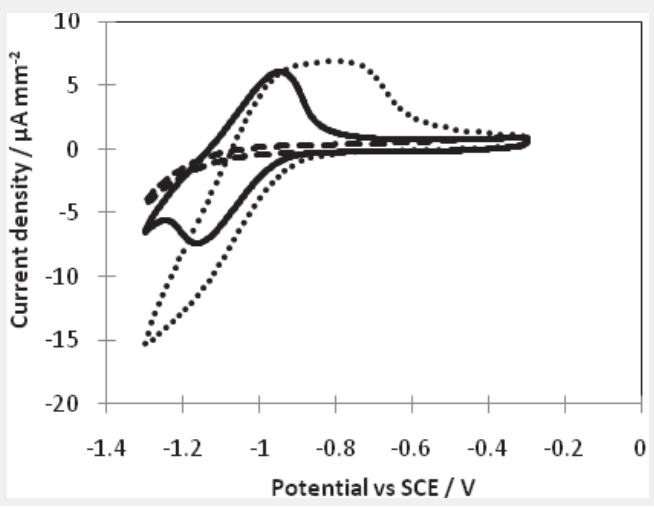

b)

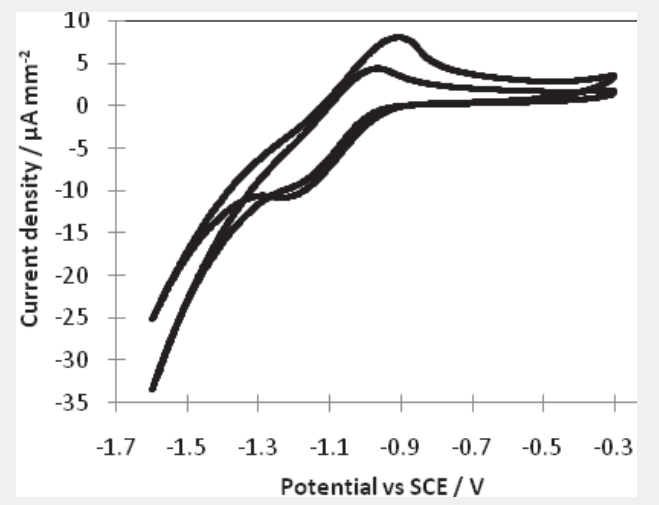




\section{ACCEPTED MANUSCRIPT}

Figure 7
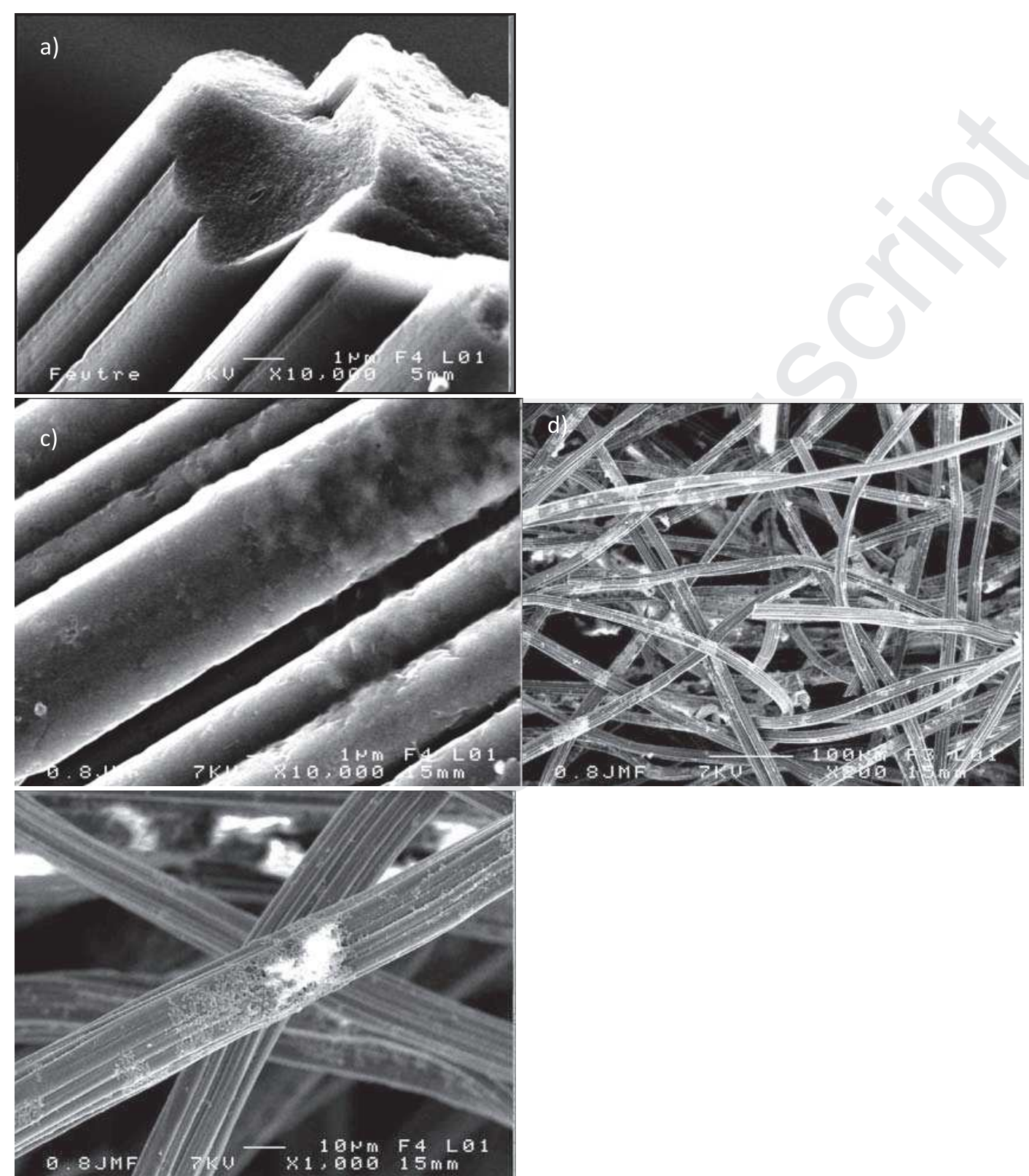
Figure 8

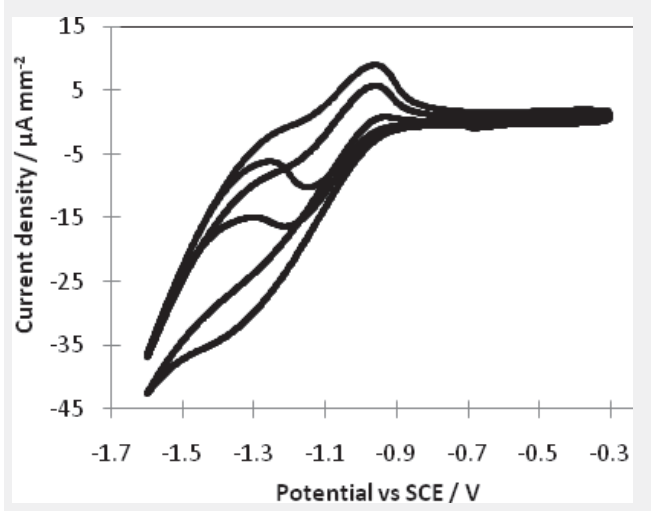


Figure 9

a)

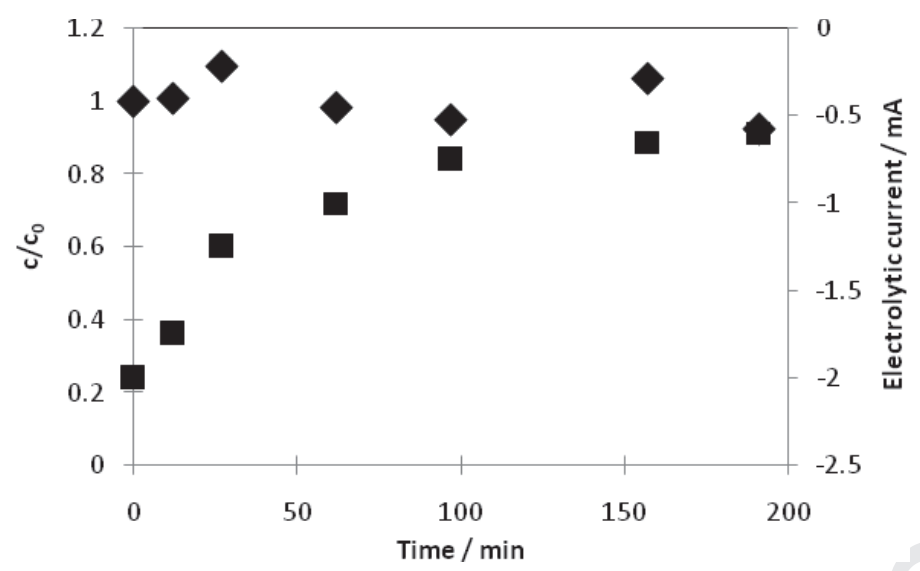

b)

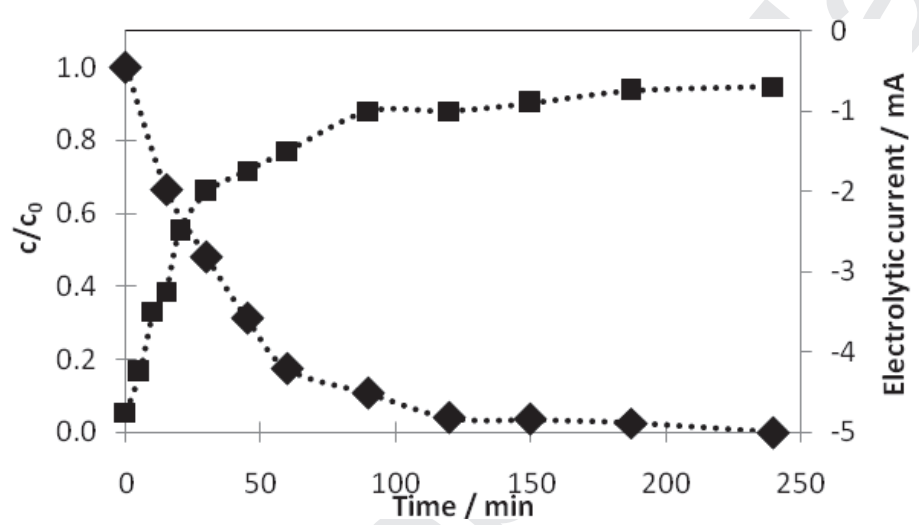

c)

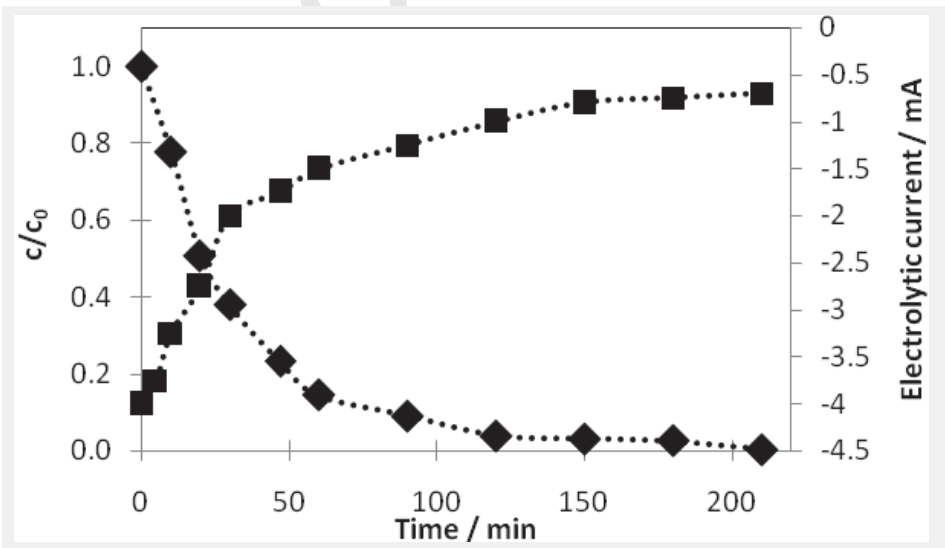


Figure 10

a)

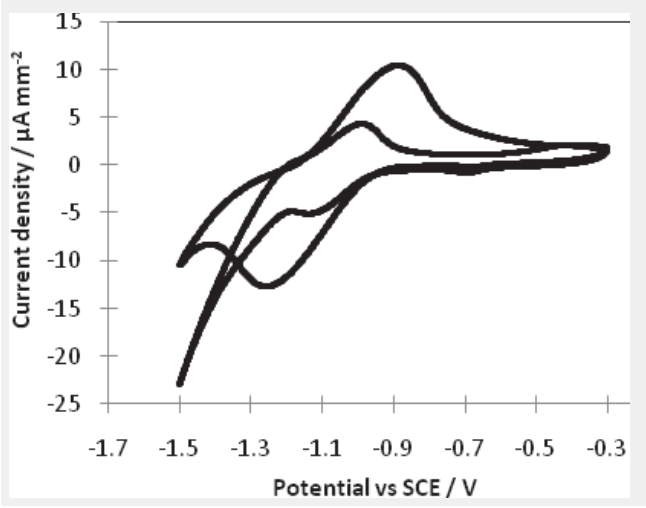

b)

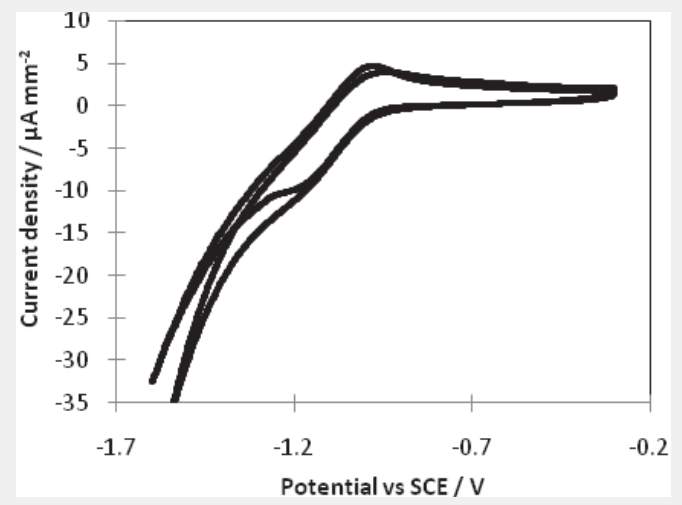

